\title{
Relationship between Social Media Promotion and Consumer Behaviors for CASIO Wristwatches in Japan, the USA, and the UK
}

\author{
Hideki Takei \\ Dept. of Information Technology and Administrative Management \\ Central Washington University \\ 400 E University Way, Ellensburg, WA, 98926. USA \\ Tel: 1-509-963-2617Ｅ-mail: takeih@cwu.edu
}

Received: January 7, $2021 \quad$ Accepted: January 30, $2020 \quad$ Published: February 28, 2021

doi:10.5296/wjbm.v7i1.18163 URL: https://doi.org/10.5296/wjbm.v7i1.18163

\begin{abstract}
CASIO standard wristwatches (C-CASIOs) have been popular topics for social media, especially in Japan, the USA, and the UK. Most of the media have shown reviews, durable tests, cerebritis who wear C-CASIOs, fashions with it, and unique stories. While C-CASIOs have been popular with such enthusiasm on the media, CASIO decided not to promote it. CASIO may not see the necessity of sales promotion because CASIO has sold it very well worldwide without the promotion. However, CASIO may not need promotion if social media in the three countries have promoted C-CASIOs. Therefore, in this paper, we will find if social media have promoted C-CASIOs for such a successful sales record.
\end{abstract}

Keywords: CASIO, Social media, Consumer behaviors, Marketing 


\section{Introduction}

CASIO standard wristwatches have been famous as cheap CASIOs (C-CASIOs, hereafter). C-CASIOs include more than 30 wristwatches with superior quality at a low price.

Because of such high quality with low prices and the powerful CASIO brand, many Japanese, the US, and British social media have talked about C-CASIOs (Manny, 2011; Winterman, 2011; Hussey, 2015; Yamamoto, 2018; Burns; 2019; Momoten, 2019). Most of the media's information is about users' reviews, durable tests, cerebritis who wear C-CASIOs, fashions with it, and unique stories.

While C-CASIOs have been popular with such enthusiasm on social media, CASIO decided not to promote C-CASIOs at all. On the CASIO's homepage, we can find only minimum product descriptions of C-CASIOs (SankeiWest, 2016; Marsden, 2019). CASIO may not see the necessity of sales promotion because CASIO has sold it very well worldwide without the promotion.

However, CASIO may not need promotion if social media have promoted C-CASIOs. Therefore, we want to find if the social media have promoted C-CASIOs for such a successful sales record. So, we checked social media in Japan, the USA, and the UK to find out. Then, we checked the actual reasons for purchases in the three countries to find any direct relation between information on social media and the actual reasons for purchases. For this study, we used Amazon's customer reviews to determine the actual reasons for purchasing two bestselling C-CASIOs: F91W and MQ24.

\section{Literature Review}

F91W is a digital wristwatch with an auto calendar, backlight, stopwatch, and a single alarm. CASIO started producing it in 1989. Since then, it has been sold more than 3 million units worldwide every year for its low price, simplicity, conventional design, reliability, and durability with superior waterproof. It has been the most popular digital wristwatch in C-CASIOs (Amazonhonyaku, 2013; Ginmi, 2017; Marsden, 2019). Wristwatch enthusiasts have called it "a masterpiece" of digital wristwatches to express the near-perfect specifications (SankeiWest, 2016; WatchMonster2, 2017; WatchMonster3, 2017).

Japanese social media mainly talk about unique stories of F91W (MAG2, 2016; WatchMonster2; 2017; Kishiken2, 2019). They talk mostly about celebrities who wear it, durability, usage in terrorism, and its retro-future style.

For example, its functionality, durability tests, and retro-future style have been trendy on YouTube (Chouyaku, 2017; WatchMonster, 2017; Yamamoto, 2018). Instagram has been a popular place for celebrities and fashion-minded young generations to post their "nerd-cool" styles with F91W. Many people have shared these videos and photos on social networks (HuffPost, 2015; Weare, 2015; WatchMonster4, 2017; Acmaoh, 2018).

Many parents have described it as the best first wristwatch for kids in schools on social media. According to many businesspersons, it has been the best business wristwatch (SankeiWest, 2016; Miurappi, 2017). It has been nostalgic for many older generations (WatchMonster2, 
2017).

The US social media have mainly shown F91W as a simple, retro-future, and low-price fashion item for youth segments instead of its quality and functions (Campbell-Dollaghan, 2012; Spence, 2015; Martel, 2016; Menga, 2019).

For example, they mention celebrities who wear it or fashionable ways of wearing it (Dash, 2009; McGuirk, 2011; Love, 2019). Some fashion-focused media describe it as the modern art of wristwatches (Cole, 2017; Jory, 2017; TheStrategist, 2019). Others say that it is an artistic tool to express minimalism, self-confidence, self-reliance, and even honorable poverty (Ben, 2015; Love, 2019). Some tell young entrepreneurs or millionaires to wear it as the fashionable second wristwatch to ROLEX (Condliffe, 2012; Jonmitchell, 2015).

While the US social media do not actively mention the toughness and functions of F91W compared to Japanese media, these seem to be still essential topics for some US social media. For example, there have been many durability tests of F91W on YouTube (Highsnobiety, 2015; Hussey, 2015; Butacu, 2018; Kaptein, 2018).

British social media have emphasized F91W's price, functions, quality, size, retro design, and toughness. They call it "a masterpiece of digital watches" (Winterman, 2011; Christian, 2013; Rossthewatcher, 2015; Richmond, 2017). Many parents and students have made it the best wrist watch for students since 2015 (Griffin, 2015; Burns, 2019).

Like Japanese and the US social media, British social media have also emphasized its retro-future style as fashionable (Irishmirrorie, 2016; Love, 2019). They usually talk about celebrities who wear it as fashionable bracelets. British YouTubers have shown it as retro-future fashion and as a tool to express minimalism, freedom from major fashion trends, antitheses for luxury life, and self-reliance (Davies, 2010; Lewis, 2014; Hambly, 2019).

MQ24 has been the most popular analog wristwatch for its low price, simplicity, readability, fashionable design, and water resistance (ChipCASI, 2019; Wakaran, 2019).

Japanese social media have mainly emphasized MQ24's essential features, such as a straightforward dial and minimal design. However, unlike F91W, there are far fewer releases of its durability tests on YouTube (Tasuyoshi, 2017; Yamada, 2017; Yome, 2018). Instead of durability tests, YouTubers have shown MQ24's beauty of simple and minimal design, beautiful color contrast between black case and white dial, and elegance of slim case and band (Momoten, 2019).

Like F91W, the media recommended using MQ24 to express female users' life philosophy, such as a non-nonsense approach in life, minimalism, environmental-friendliness, self-reliance, or simplicity (Fuku, 2017; Show, 2017; ChipCASI, 2019). Social media of non-wrist-watch-users have recommended wearing MQ24 for occasions when they cannot check the time on smartphones (Bouzu, 2015; Sapico, 2016; Kanego, 2018; FIDN, 2019; Kurimaru, 2019; Wakaran, 2019).

MQ24 has not been popular on the US social media in comparison to F91W. When they talk about it, they usually describe it as a masterpiece of analog wristwatches and an excellent 
choice for minimalists (Manny, 2011; Jonmitchell, 2015; Schneider, 2018; Editors, 2019). They talk about celebrities who wear them. They emphasize its simplified design as fashionable for young females (Snavely, 2014; TIMELESS, 2018; G-central, 2019).

MQ24 has rarely appeared on British social media. Some describe it as fashionable due to simplified and unisex design (Brock, 2019; Burns, 2019; TWB, 2019).

\section{Research Method}

To find any direct relation between social media information and the actual reasons for purchases, we searched for F91W and MQ24 on social media in Japan, the USA, and the UK. We then collected customer reviews on Amazon in the three countries to find customers' reasons for purchases. For F91W, we checked 288 reviews for Japan, 336 reviews for the USA, and 201 reviews for the UK. For MQ24, we checked 213 reviews for Japan, 336 reviews for the USA, and 282 reviews for the UK.

\section{Results}

For F91W, social media in the three countries shared similar topics. First, they have called it a masterpiece of digital wristwatches for superior quality, functions, and durability.

While its low price is also one of the most significant parts of making it a masterpiece, they emphasized it indirectly as an additional value to superior quality, functions, and durability.

Second, they have delivered many stories about F91W's durability. They talk about a still-working 20-year-old F91W, which the owner lost it in his garden 20 years ago. YouTubers actively show various durability tests. For example, they bring it to the deep sea, throw it from top of a building, run it over by a car, or step it over on foot. Most of the time, they will not be able to break it.

Third, they have described F91W as a fashion item; however, the watch's fashion sense is different in the three countries. Japanese social media have focused on the fashion sense of celebrities who wear it, while the US social media have emphasized minimal and straightforward fashion. Some of the US media even suggest their audiences wearing it to express minimalism and simple life orientation. British social media have emphasized its 1980s retro-future design.

We also found differences. Most Japanese social media talk about unique stories about F91W, while the US and British media are not interested in such stories. Japanese media love stories such as Osama bin Laden was wearing it, al-Qaeda was using it in ticking bombs, Mr. Obama was wearing it, and many celebrities were wearing it.

Table 1 shows F91W's customer reviews on Amazon in the three countries. Japanese customers bought it for its low price (32.3\%), its stories and celebrities wearing it $(31.3 \%)$, and its functions and quality (21.8\%). The US customers bought it for its low price $(51.8 \%)$, its functions and quality (48.2\%), and its comfort in wearing (14.3\%). British customers bought it for its functions and quality $(65.7 \%)$, and its low price $(64.2 \%)$, and its simple and minimal design (10.4\%). 
Table 1. Customer Reviews F91W

\begin{tabular}{|c|c|c|}
\hline Japan & USA & UK \\
\hline Low Price & Low Price & Functions \& Quality \\
$(32.3 \%)$ & $(51.8 \%)$ & $(65.7 \%)$ \\
\hline Stories \& Celebrities & Functions \& Quality & Low Price \\
$(31.3 \%)$ & $(48.2 \%)$ & $(64.2 \%)$ \\
\hline Functions \& Quality & Comfort in wearing & Simple \& Minimal Design \\
$(21.8 \%)$ & $(14.3 \%)$ & $(10.4 \%)$ \\
\hline
\end{tabular}

For MQ24, the media have emphasized its minimal and simple design in the three nations. They showed it as the best analog watch for all minimalists, a wristwatch-style-bracelet, and a wristwatch with simplified beauty.

Its durability is not a topic in the media, even if it is an exceptionally durable watch. Instead, they emphasize their fashionable sides. YouTubers have shown various ways to wear it in stylish ways instead of conducting durability tests.

MQ24 seemed not to be a popular item on the US and British social media. While Japanese social media will always mention MQ24 whenever they talk about F91W, the US and British social media usually only talk about F91W.

Table 2 shows MQ24's customer reviews on Amazon in the three countries. Japanese customers bought it for its simple and minimal design (45.0\%), its low price (40.8\%), and its comfort in wearing (36.6\%). The US customers bought it for its function and quality $(50.0 \%)$, its low price (49.1\%), and its comfort in wearing (13.4\%). The UK customers bought it for its function and quality (43.6\%), and its low price (30.9\%), and its fashionable style (29.8\%).

Table 2. Customer Reviews MQ24

\begin{tabular}{|c|c|c|}
\hline Japan & USA & UK \\
\hline Simple \& Minimal Design & Function \& Quality & Function \& Quality \\
$(45.0 \%)$ & $(50.0 \%)$ & $(43.6 \%)$ \\
\hline Low Price & Low Price & Low Price \\
$(40.8 \%)$ & $(49.1 \%)$ & $(30.9 \%)$ \\
\hline Comfort in wearing & Comfort in wearing & Fashion \\
$(36.6 \%)$ & $(13.4 \%)$ & $(29.8 \%)$ \\
\hline
\end{tabular}

Social and mainstream media in the three nations have delivered similar topics about F91W. They call F91W a masterpiece of digital wristwatches for superior quality, functions, and durability; one of the most robust digital wristwatches; and a fashion item for young people. However, only Japanese media mention many unique stories making it a legendary 
wristwatch.

F91W's customer reviews showed that "low price" and "functions and quality" were dominant reasons for purchases in the three countries. $14.3 \%$ of the US customers pointed out "comfort in wearing." $10.4 \%$ of British customers pointed out "simple and minimal design." More than $30 \%$ of Japanese customers purchased F91W because it has unique stories or celebrities wear it.

Interestingly, F91W's durability was not a dominant reason in the three nations. Instead, most customers in the three countries looked for a cheap and very basic wristwatch for everyday use. According to reviews, we could see that they happened to find F91W during their searches for an affordable and very basic wristwatch on Amazon.

The media in the three countries have emphasized the minimal, simple, and fashionable design of MQ24. They show it as the best analog watch for minimalists, a wristwatch-style-bracelet, and a wristwatch with simplified beauty. However, the US and British social media are not enthusiastic about it compared to Japanese social media. We could not find so much information about MQ24 in the US and British social media.

According to the customer reviews, customers in the three countries pointed out the "low price" of MQ24 was the dominant reason for their purchases. In addition to this reason, the US and British customers pointed out the "function and quality" as another dominant reason. Only Japanese customers said "Simple and Minimal Design" as a dominant reason. Almost $30 \%$ of British customers pointed out "fashion" as a dominant reason. Both Japanese and the US customers said "comfort in wearing" was another dominant reason.

It seems like Japanese customers purchased it as a cheap and comfortable analog wristwatch with a fashionable design. The US customers bought MQ24 as a cheap and functional analog wristwatch with comfort in wearing. British customers bought MQ24 as a fashionable cheap analog wristwatch with high quality. Similar to the case of F91W, we could see that they happened to find MQ24 during their searches for an affordable and very basic wristwatch on Amazon.

\section{Conclusion}

Social and mainstream media in Japan, the USA, and the UK have delivered similar topics about F91W. However, customer reviews on Amazon in the three countries showed only partial influence from the media.

Except for Japanese customers who bought F91W for its stories and celebrities wearing it, customers in the three countries purchased it as a cheap and very basic digital wristwatch for everyday use. They even seemed to find it by chance during their searches for a basic digital wristwatch.

While social media in the three countries have delivered similar messages about MQ24 to their audiences, customer reviews on Amazon in the three countries were only partially influenced by the media. 


\section{Ml Macrothink}

World Journal of Business and Management ISSN 2377-4622 2021, Vol. 7, No. 1

The partial influences are "simple and minimal design" for Japanese customers and "Fashion" for British customers. However, these can be something they noticed when they looked at MQ24 on Amazon. Therefore, it is difficult for us to say these are even partial influences from social media. Many customers in the three countries purchased it for a low price and quality. Similar to F91W, they happened to find MQ24 during their searches for a cheap analog wristwatch. When they checked it, they noticed comfort in wearing because it was small and came with a soft rubber band.

Based on our research, many customers bought C-CASIOs on Amazon because they happened to find it during "self-searches" for cheap and basic wristwatches. They noticed and bought C-CASIOs through the self-searches on Amazon means C-CASIOs' self-promotion. Self-promotion means that a product can promote itself without active advertisements as its features match customers' needs. Casio's decided not to promote C-CASIOs because of such excellent specifications of C-CASIOs, which will work as self-promotion tools. Through this study, we could see the effective self-prom

\section{References}

Acmaoh. (2018, September 30). CASIO F-91W-1JF: This is the only watch you need! Retrieved from https://www.youtube.com/watch?v=EVvU-TGOLkg

Amazonhonyaku. (2013, October 31). For terrorists? People are impressed by toughness of CHEAP-CASIO. Retrieved from https://amazonhonyaku.com/レビュー/チープカシオ腕時 計 f-91w/

Ben. (2015, September 28). An ode to the Casio F-91W, the only watch you'll ever need. Retrieved from https://thetab.com/2016/03/07/ode-casio-f-91w-watch-youll-ever-need-78198

Bouzu. (2015, June 3). A simple way to change a battery for a simple wristwatch CASIO $M Q-24$. Retrieved from https://bouzuseikatsu.com/casiomq-24/

Brock. (2019, July 14). 25 Great Watches For Small Wrists (Updated for 2019). Retrieved from https://www.themodestman.com/watches-for-small-wrists/

Burns, S. (2019, August 7). Perfect Watches For Men With Small(er) Than Average Wrists. Retrieved from https://www.toolsofmen.com/watches-for-small-wrists/

Butacu, R. (2018, October 11). Why do people buy overpriced watches? What's wrong with a simple Casio? Retrieved from https://www.quora.com/Why-do-people-buy-overpriced-watches-Whats-wrong-with-a-simple -Casio

Campbell-Dollaghan, K. (2012, October 5). Hacking A Classic Casio Watch To Turn It Into Wearable Art. Retrieved from https://www.fastcompany.com/1670932/hacking-a-classic-casio-watch-to-turn-it-into-wearabl e-art

ChipCASI. (2019, January 1). The first watch for you: All about CASIO MQ24. Retrieved from http://チープカシオ.com/mq-24/ 


\section{Al Macrothink}

World Journal of Business and Management

ISSN 2377-4622

2021, Vol. 7, No. 1

Chouyaku. (2017, October 20). CASIO F91, made since 1991, the best selling wrist watch of AMAZON. Retrieved from http://chouyakuc.blog134.fc2.com/blog-entry-208.html?sp

Christian. (2013, February 14). My most accurate watch - the Casio F-91W. Retrieved from https://watchguy.co.uk/my-most-accurate-watch-the-casio-f-91w-2/

Cole, S. (2017, April 14). People Love Modding Old Casio Watches. Retrieved from https://www.vice.com/en_us/article/kbv8qa/people-love-modding-old-casio-watches

Condliffe, J. (2012, January 17). Nobody Needs a Watch Any Fancier Than a Casio Digital. Retrieved from https://gizmodo.com/nobody-needs-a-watch-any-fancier-than-a-casio-digital-5876727

Dash, A. (2009, January 25). President Obama's Watch. Retrieved from https://anildash.com/2009/01/25/president_obamas_watch/

Davies, R. M. (2010, January 19). The irrationality of the watch. Retrieved from https://www.wired.co.uk/article/russell-davies-watches

Editors. (2019, April 23). The Best Men's Sports Watches on Amazon, According to Hyperenthusiastic Reviewers. Retrieved from http://nymag.com/strategist/article/best-mens-sports-watches.html

FIDN. (2019, January 20). Reasons why I bought CASIO Analogue Watch MQ-24-7B2LLJF: Reviews of the watch. Retrieved from https://www.lancork.net/2015/10/cheap-casio-mq-24-review/

Fuku. (2017, Nobember 25). Tesing water proof of Cheap-CASIO MQ-24. Retrieved from https://fuku-labo.com/casio-standard-mq-24

G-central. (2019, May 1). Rich and Powerful Men Who Wear Casio Watches. Retrieved from https://www.g-central.com/rich-and-powerful-men-who-wear-casio-watches/

Ginmi. (2017, March 15). Fashionable and popular: CASIO F91, Osama bin Laden Model, will go for more than 20 years. Retrieved from https://ginmi.xyz/874

Griffin, A. (2015, May 12). 10 best men's digital watches. Retrieved from https://www.independent.co.uk/extras/indybest/gadgets-tech/best-mens-digital-watches-1024 5261.html

Hambly, M. (2019, March 26). Casio Watches: 5 of the Best to Buy. Retrieved from https://www.menshealth.com/uk/style/a758941/casio-watches-to-buy-right-now/

Highsnobiety. (2015, September 14). Is the Casio F-91W Watch the Ultimate Terrorist Timepiece? Retrieved from https://www.highsnobiety.com/2015/09/14/casio-f-91w-terrorist-bomb/

HuffPost. (2015, June 19). Found a lost Cheap-CASIO after 20 years: Impressing us for its toughness. Retrieved from https://www.huffingtonpost.jp/2015/06/19/i-found-casio-watch-20-years_n_7618810.html 
Hussey, M. (2015, October 20). How the Casio F-91W became the world's most versatile (and dangerous) watch. from https://thenextweb.com/insider/2015/10/20/how-the-casio-f-91w-became-the-worlds-most-ve rsatile-and-dangerous-watch/

Irishmirrorie. (2016, September 29). Ten reasons we love our Casio F-91W digital watch. Retrieved from https://www.irishmirror.ie/news/weird-news/ten-reasons-love-casio-f-8938774

Jonmitchell. (2015, April 20). Casio MQ24 Watch Review. Retrieved from https://jonmitchell.net/blog/casio-mq24-watch-review

Jory. (2017, February 21). The Casio Challenge. Retrieved from https://manoverboard.com/the-casio-challenge/

Kanego. (2018, February 21). I bought a Cheap-CASIO. Retrieved from https://kanegolabo.com/cheep-casio-mq24

Kaptein, M. (2018, September 5). The 10 reasons of why I consider the Casio F-91W to be the best watch in the world. Retrieved from https://www.martinkaptein.com/blog/10-reasons-casio-f-91w-best-watch/

Kishiken. (2016, October 7). Cheap-CASIO which Mr. Obama and many celebrities wear. Retrieved from https://kishiken.com/diary/fashion/cheep-casio-watch.html

Kishiken2. (2019, September 29). Changing a belt to make Cheap-CASIO F84W fashionable. Retrieved from https://kishiken.com/diary/fashion/casio-belt-exchange.html

Kurimaru. (2019, April 23). Cheap-CASIO MQ-24-7BLLJF: The greatest 1000-yen watch. Retrieved from https://kurisatsuma.com/mq-24-7blljf/

Lewis, R. (2014, July 8). Journeys with a Casio F91-W. Retrieved from http://robertlewis.com/blog/journeys-casio-f91-w/

Love, Z. (2019, April 25). The Classic Casio F-91W Is the Cheapest Watch Worth Buying. Retrieved from https://gearpatrol.com/2019/04/25/classic-casio-f-91w-cheapest-watch-worth-buying/

MAG2. (2016, September 30). ¥1000 shock: Why did consumers choose cheap-CASIO twice? Retrieved from https://www.mag2.com/p/news/221579

Manny. (2011, August 3). A Review of Casio Classic Quartz MQ-24-1ELDF MQ-24-1E MQ24-1E Men's Watch. Retrieved https://www.creationwatches.com/watchblog/casio/a-review-of-casio-classic-quartz-mq-24-1 eldf-mq-24-1e-mq24-1e-mens-watch.html

Marsden, D. (2019, August 11). Casio F-91W - the classic quartz digital watch. Retrieved from https://www.iconeye.com/opinion/icon-of-the-month/item/9473-casio-f-91w

Martel, C. (2016, August 26). The Venerable Casio F-91W: The Digital Watch That Took 
Over

the

World.

Retrieved

from

https://watchesyoucanafford.com/the-venerable-casio-f- $91 \mathrm{w}$-digital-watch-the-digital-watch-t hat-took-over-the-world/

McGuirk, J. (2011, April 28). Casio's F-91W watch: The design favourite of hipsters ... and al-Qaida. Retrieved from https://www.theguardian.com/artanddesign/2011/apr/28/casio-f-91w-watch-design-hipsters-al -qaida

Menga. (2019, January 1). Is the Casio F-91W the best wristwatch in the world? Retrieved from https://menga.net/is-the-casio-f-91w-the-best-wristwatch-in-the-world

Miurappi. (2014, December 23). Useful wrist watch: Cheap-CASIO. Retrieved from https://nyanyanyapo.blog.fc2.com/blog-entry-63.html

Momoten. (2019, May 22). Reviews of fashionable and popular MQ-24. Retrieved from https://korasyosx.hatenablog.com/entry/2019/05/22/002622

Richmond, M. (2017, July 28). Casio F-91W: The Best Wristwatch in the World? Retrieved from https://wristwatchreview.co.uk/casio-f-91w

Rossthewatcher. (2015, June 27). The £7 Wrist Watch: Casio F-91W-1YER Review. Retrieved from https://watchuupto.com/watches/the-8-wrist-watch-casio-f-91w-1yer-review/

SankeiWest. (2016, September 23). "950 yen!” No need of profit from cheap Citizen and CASIO. Retrieved from https://www.sankei.com/west/news/160923/wst1609230002-n1.html

Sapico. (2016, October 20). 108 yen to change a battery of CASIO MQ-24: It's so easy! Retrieved from https://blog.sapico.net/entry/チープカシオ MQ-24 電池交換

Schneider, M. (2018, January 1). The 12 Best Men's Watches Under \$50. Retrieved from https://brobible.com/gear/article/best-mens-watches-under-50/

Show. (2017, April 17). Cheap-CASIO Reviews: MQ-24-7B2 \& MQ-71-4B. Retrieved from https://カシオ腕時計.biz/チープカシオ・レビュー-mq-24-7b2-x-mq-71-4b/

Snavely, A. (2014, January 1). Your New \$12 Black-on-Black Watch: The Casio MQ24-1E. Retrieved from https://www.primermagazine.com/2014/spend/your-new-12-black-on-black-watch-the-casiomq24-1e

Spence, E. (2015, March 29). Lessons For The Future From The World's First Smartwatch. Retrieved from https://www.forbes.com/sites/ewanspence/2015/03/29/casio-f-91w-review/\#3768573c5e70

TASCLAP. (2019, July 3). Not really cheap looking: Selected Cheap-CASIO. Retrieved from https://mens.tasclap.jp/a388

Tasuyoshi. (2017, November 18). Cheap-CASIO MQ-24-7BLLJF is your partner! Retrieved from http://www.tatsuyosi.net/entry/casio-watches 


\section{Macrothink}

World Journal of Business and Management ISSN 2377-4622 2021, Vol. 7, No. 1

TheStrategist. (2019, April 23). The Best Men's Sports Watches on Amazon, According to Hyperenthusiastic Reviewers. Retrieved from http://nymag.com/strategist/article/best-mens-sports-watches.html

TIMELESS. (2018, November 20). Are there extremely famous and wealthy people with inexpensive watches? Retrieved from https://forums.watchuseek.com/f2/there-extremely-famous-wealthy-people-inexpensive-watc hes-4833963.html

TWB. (2019, January 1). Casio G-Shock Men's Watch MQ24/7B Review. Retrieved from https://www.thewatchblog.co.uk/casio-g-shock-mens-watch-mq247b-review/

Wakaran. (2019, January 1). CASIO MQ-24-7B2LLJF and MQ-24-7BLLJF. Retrieved from http://www13.plala.or.jp/wakaran/cheap_casio.html

WatchMonster. (2017, January 17). Checking toughness of Cheap CASIO. Retrieved from https://watch-monster.com/articles/BRwLM

WatchMonster2. (2017, January 17). Finding attractiveness of Cheap-CASio. Retrieved from https://watch-monster.com/articles/qpgdI

WatchMonster3. (2017, January 17). Making Cheap-CASIO more attractive by yourself at low cost. Retrieved from https://watch-monster.com/articles/gqlWV

WatchMonster4. (2017, January 17). Cheap-CASIO that Nottchi of Perfume was wearing. Retrieved from https://watch-monster.com/articles/im5Ef

Weare, M. (2015, September 30). 7 Ingeniously Japanese Watches. Retrieved from http://goyaku.blog45.fc2.com/blog-entry-859.html

Winterman, D. (2011, April 26). Casio F-91W: The strangely ubiquitous watch. Retrieved from https://www.bbc.com/news/magazine-13194733

Yamada, T. (2017, May 10). Cheaper than 1000-yen! High cost-performance! A simple analogue wrist watch Cheap-CASIO MQ-24. Retrieved from https://y-ta.net/mq-24/

Yamamoto, Y. (2018, August 14). Cheap-CASIO's quality and functions have been re-recognized by consumers. Retrieved from http://net.keizaikai.co.jp/archives/31528

Yome. (2018, February 18). Cheapest price of cheap-CASIO, Gen Hoshino Model (MQ-24-7B2LLJF), on AMAZON? Retrieved from https://yome-talk.com/cheap_casio-udedokei-hosino_gen-model-mq247b2lljf-amazon-2575/

\section{Copyright Disclaimer}

Copyright for this article is retained by the author(s), with first publication rights granted to the journal.

This is an open-access article distributed under the terms and conditions of the Creative Commons Attribution license (http://creativecommons.org/licenses/by/3.0/). 